\title{
A Framework for Improving Project Performance of Standard Design Models in Saudi Arabia
}

\author{
Shabbab Al-Otaibi ${ }^{1}$, Mohamed Osmani ${ }^{2}$, and Andrew D.F. Price ${ }^{3}$ \\ ${ }^{1}$ Senior Lecturer, Civil Engineering Department, Shaqra University, P.O. Box 33, Shaqra 11961, Saudi Arabia. Email: \\ dr.alhammadi@su.edu.sa (Corresponding author). \\ ${ }^{2}$ Senior Lecturer, School of Civil and Building Engineering, Loughborough University, Loughborough, LE11 3TU, \\ Leicestershire, United Kingdom. E-mail: m.osmani@lboro.ac.uk \\ ${ }^{3}$ Professor, School of Civil and Building Engineering, Loughborough University, Loughborough, LE11 3TU, \\ Leicestershire, United Kingdom. E-mail: a.d.f.price@lboro.ac.uk
}

Project Management

Received August 25, 2012; received revision October 4, 2012; accepted October 10, 2012

Available online December 13, 2012

\begin{abstract}
Improving project performance in the construction industry poses several challenges for stakeholders. Recently, there have been frequent calls for the importance of adopting standardisation in improving construction design as well as the process and a focus on learning mapping from other industries. The Saudi Ministry of Interior (SMoI) has adopted a new Standard Design Model (SDM) approach for the development of its construction programme to effectively manage its complex project portfolio and improve project performance. A review of existing literature indicates that despite the adoption of SDM repetitive projects, which enable learning from past mistakes and improving the performance of future projects, it has been realised that there is a lack of learning instruments to capture, store and disseminate Lessons Learnt (LL). This research proposes a framework for improving the project performance of SDMs in the Saudi construction industry. Eight case studies related to a typical standard design project were performed that included interviews with of 24 key stakeholders who are involved in the planning and implementation of SDM projects within the SMoI. The research identified 14 critical success factors CSFs have a direct impact on the SDM project performance. These are classified into three main CSF-related clusters: adaptability to the context; contract management; and construction management. A framework, which comprises the identified 14 CSFs, was developed, refined and validated through a workshop with 12 key stakeholders in the SMoI construction programme. Additionally, a framework implementation process map was developed. Web-based tools and KM were identified as core factors in the framework implementation strategy. Although many past CSF-related studies were conducted to develop a range of construction project performance improvement frameworks, the paper provides the first initiative to develop a framework to improve the performance of standard design and repetitive projects.
\end{abstract}

Keywords: Standard Design Models, project performance improvement, construction industry, Saudi Arabia.

\section{Introduction}

The improvement of performance has become ever more critical to the success of construction projects and has been the subject of a considerable amount of research and attention over the past two decades. Smyth (2010) pointed out that there has been a range of initiatives across many countries over the last 10 to 15 years to introduce reform to the construction process in order to improve performance. Particularly, the Saudi Arabian construction industry is of interest due to the current rapid growth of the Saudi economy, and the significant number of large construction projects being implemented in both the public and the private sectors. Although a considerable construction programme is underway, there is a concern associated with the frequent and lengthy delays that have caused underachievement in project performance (Al-
Kharashi and Skitmore, 2009). Arain et al. (2006) identified that the inconsistencies between design and construction have a significant impact on construction project performance in Saudi Arabia. The Egan (1998) and Latham (1994) reports highlighted the need to improve the design and construction process and suggested that improvement could be achieved by reducing the number of variations and resistance to adopt a shared learning program. Egan focused on the issues of product development and project implementation which can be achieved through the adaption of a generic product on a specific site. As such, innovation and shared learning can be achieved and enable sustained improvement. Many frameworks have been developed in the interim and have coexisted with different approaches and this has resulted in a dilemma of choice, between number and variation of 
available frameworks. These frameworks were developed for specific projects that were not designed as repetitive projects.

The SDM approach was developed based on standardising design, specifications, materials and processes as well as standardised procedures in the construction phase. However, the current use of this approach does not work perfectly due to lack of a valid framework (SAD, 2006). Many authors have emphasised the need of defining the critical success factors (CSFs) that are used in improving the performance of projects and significantly leading to successful project delivery (Chan et al., 2001; Cooke-Davies, 2002). The studies involved different construction projects, for instance: general construction projects (Ashley et al., 1987; Pinto and Slevin, 1988; Savindo et al., 1992; Chua et al., 1999; Egbu, 1999; Phua and Rowlinson, 2004; Fortune and White, 2006), and design-build projects (Songer and Molenaar, 1997; Ng and Mo, 1997; Chan et al., 2001). However, there is no apparent consensus among researchers on CSFs on construction projects (Toor and Ogunlana, 2009). Scholars have advocated that CSFs should be related to one another with underlying connected relationships (Johnston et al., 1999). However, in general, the lack of literature on this subject reveals that not much has been published on CSFs for repetitive or standard design projects and in particular in the context of the Saudi Arabian construction industry.

It is widely accepted that there is a need to address the excessive fragmentation and high design costs by integrating the design and construction processes to achieve sustained performance improvement. This concern has led the Saudi Ministry of Interior (SMoI) to adopt Standard Design Models SDMs to implement its construction programme and deliver better value as well as a more effective project management strategy. Lessons have to be learnt from the re-use of SDMs for subsequent projects and from sharing and learning from on-going projects (Alotaibi et al., 2007, 2008). A review of existing literature related to SDM projects (SAD, 2008) indicates that despite the adoption of SDM repetitive projects, which enable learning from past mistakes and thus improve the performance of future projects, it has been reported that there is a lack of learning instruments to capture, store and disseminate lessons learnt (LL), which has recently resulted in poor performance and long delays in the implementation of SDM projects. However, in the Saudi construction industry and specifically in the SMoI projects, there appears to be no formalised improvement framework that incorporates CSFs and learning, particularly in relation to the SDMs. The aim of this paper, therefore, is to develop a framework that improves the performance of SDMs in the SMoI projects.

\section{Literature Review}

This literature aims to discuss the challenges facing performance improvement in construction projects and the processes that could be used to achieve this improvement. It also discusses how to measure the success of projects through identifying the CSFs that lead to this success. This literature covers learning in the construction industry and the positive impacts of LL.

\subsection{Projects Performance Improvements}

Improving project performance in the construction industry poses several challenges for stakeholders.
Additionally, it is not an easy task to sustain radical improvement in a diverse environment such as the construction industry (Egan, 1998). It requires the identification and implementation of suitable improvement programmes subjected to the construction business cycle (Tang and Ogunlana, 2003). This is important since the integration of improvement programmes in construction may incur high cost and yet the benefit can only be realised in the long term (Takim, 2005). However, there is a need for new improvement programmes and initiatives at various stages of a project life-cycle in order to enhance construction project performance and target changing trends of private and public sector construction project organisations (Tang and Ogunlana, 2003; Atkinson, 2003). Such programmes entail the integration and implementation of process improvements across project phases.

Process improvement in the development of construction projects is necessary to enhance the performance of projects, in particular of large-scale projects and to mitigate the problems of adversarial relationships. For example, the UK construction industry has made advances since the publication of the (Egan, 1998). The establishment of the Construction Best Practice Programme, the Movement for Innovation, and the new establishment of Construction Excellence have helped to promote management techniques such as benchmarking partnering, lean construction, supply chain management, and risk management, all of which are more prevalent within UK construction companies (Barrie, 1999; Cook, 1999; DETR, 1999a; Dainty et al., 2003).

The good performance that comes with a successful completion of large-scale construction projects is considered a serious challenge. Therefore, identification of CSFs becomes crucial. Chua et al. (1999) noted that there is a general agreement among experts regarding the variety of CSFs for different projects' objectives. Liu (1999) argued that there is a specific set of success factors related to one project that may not be transferable to another project. Similarly, Belout and Gauvreau (2004) indicated that there are variations between projects with respect to allocated budget and schedule, quality standards and a series of complex and interrelated activities, although some common characteristics do exist. However, CSFs could be identified at all phases of project either design, tendering or construction (Takim, 2005; Belassi and Tukle, 1996; Chan and Kumaraswamy, 1995).

Significantly, there are several tools that have a significant impact of a success of project as well as the use for improving project performance, including: benchmarking, partnering and LL.

\subsection{Lessons Learnt}

It might be that the concept of a learning organisation is a 'new' idea to construction organisations, although the concept is well established in the management field (Chinowsky et al., 2007). Similarly, this was recognised within the context of SDM projects (Alotaibi et al., 2007, 2008). The learning process relates to how companies absorb knowledge and other stimulus from experience due to internal and external environments and thus how acquired knowledge is employed to achieve continuous improvement (Kululanga et al., 1999). However, the learning environment is playing a vital role on the outcome of acquired knowledge. There are two levels of 
learning environment: technical-organisational learning and social learning. In this regard, Kalsaas (2012) discussed that it should be a distinction between the two levels where the technical-organisational learning environment relates closely to the material conditions and the approved method of doing the work within the organisation which offers the possibilities of potential learning. On the other hand, the social learning environment relates to the work community and social interaction. He mentioned that the learning progress is affected by labour's background, age as well as capacity to benefit from learning.

Lessons learnt (LL) are emerging as one of the essential tools for driving the project improvement wheel and may soon become one of the key sources of competitive advantage (Goh and Richards, 1997). Snider et al. (2000) stated that although the idea of learning from experience is timeless, the close attention given to formalising systems for capturing and disseminating LL within an organisation has recently been realised. Nowadays, LL have become the language of improvement. Most industries have become acutely aware of their significant role in achieving continuous improvement for their performance sectors in order to survive in a competitive environment. At this time, the construction industry, known for its fragmentation and traditional culture, lags behind other industries in its project performance. Practically, LL are still suffering from a lack of attention and commitment by all stakeholders. Weiser and Morrison (1998) noted that systematic methods of identifying, capturing and transferring LL for future projects are still to be found in very few firms. Recently, Tan et al. (2007) proposed a methodology for the live capture and reuse of project knowledge in the construction industry. This approach comprised a web-based knowledge bank; an integrated workflow system and a project knowledge manager as the administrator, thereby allowing project knowledge to be captured live from ongoing projects. It also incorporated mechanisms to accelerate knowledge validation and the dissemination of knowledge once it has been validated. Nevertheless, in this research the improvement framework was developed based on the concept of LL that could be circulated through the phases of SDM projects including on-going and future projects due to their repetition . On the other hand, a majority of the developed frameworks identified from literature focus on learning levels and mechanisms rather than what type of project and how they could be implemented to repetitive projects (Crossan et al., 1997, 1999; Gieskes and Broeke, 2000; Law and Chuah, 2004). Therefore, a framework could be challenged during the implementation phase due to the differences that exist between other projects and the need for a similar context comparing with the situation of SDM repetitive projects.

\section{Research Methods}

Due to the infancy of the SDM approach, which was recently adopted by the Saudi construction industry, and because there are limited publications related to SDM projects within the context of Saudi construction; this type of project is regarded as a contemporary phenomenon within some real-life context, "how" or "why" questions are being posed (Yin, 2008). Consequently, a case study strategy was adopted in this paper as an in-depth investigation into the current SDM projects performance to determine how LL are being captured, stored and used as an improvement tool in such projects; provide an indepth insight into the current performance of SDM projects; and identify CSFs affecting the improvement of SDM projects performance through LL.

The case studies used two data collection methods: semi-structured interviews and SMoI SDM-related documents. Semi-structured interviews were selected as a style of interviewing to give form to the interviews whilst allowing probing (Hussey and Hussey, 1997; Fellows and Liu, 2008). The semi-structured interviews were held with 24 key stakeholders who are involved in the planning and implementation of the SDM projects. In each case study, three representatives were selected, including the client, consultant and contractor. Furthermore, SMoI SDM related documents such as performance assessment reports, invitation documents, tendering documents, bills of quantities (BoQ) documents, project contract documents, financial requests, minutes of meetings, change order documents, submittal request documents, prequalification request documents, disseminated documents and the project handover to end-user documents were used and analysed as SDM project-related archives to gather the needed information relevant to the eight cases. Each interview lasted between 90 to 120 minutes to cover the identified issues and to ensure that the necessary information was obtained. The interview sessions were taped, at the interviewee's discretion, transcribed and coded. The template developed for the interviews includes personal background, learning in SDM projects and SDM project performance and identifying the CSFs which are related to each stage of SDM projects.

A framework analysis technique was used to analyse the interviews (Ritchie and Spencer, 1994), whereas documents were analysed by using qualitative content analysis (Bryman, 2008). A cross-case synthesis technique was used to analyse the eight cases because it is likely to be easier and the findings are likely to be more robust when a study consists of more than two cases (Yin, 2008). Findings from the eight case studies in both interviews and documents analysis were synthesised through cross-case identified CSFs used in SDM projects. The next stage was the validation check if the model/framework behaves as the real world under the same conditions (Miser, 1993; Pidd, 2009). Pidd (2009) indicated that the historical and social perspectives suggest that a framework becomes valid when it obtains acceptance by the surrounding experts and the scientific community. Moreover, there are no unanimous criteria for validation; hence, any validity judgement depends on the situation in which the proposed model/framework is adopted and on the phenomenon being modelled (Miser, 1993). Qualitative frameworks could be validated using a qualitative approach through interviews and survey techniques while highlighting the advantages and disadvantages of the framework in the validation process (Smith, 1993). A validation workshop was held in Saudi Arabia for 12 stakeholders who are involved in the implementation of SDM projects. The workshop activities comprised a short presentation on the background of the research, the proposed improvement framework and highlights of the recent legislative developments related to the research, followed by discussions on the applicability and practicality of the proposed framework for improving the performance of SDMs in SMoI projects.

\section{Findings}


The findings from the eight case studies for both the documents and interviews were synthesised through 14 cross-case identified CSFs. These factors were deemed collectively by the research participants to have a significant impact on the process of improving the SDM projects'- performance, as shown in Table 1. These CSFs were classified into three main themes:' the adaptability of the SDMs to their context'; 'contract management'; and 'construction management'. This classification was based on the relationships between each factor and theme as identified from the data analysis and as used in the context of SDM projects.

Table 1. CSFs identified from eight case studies

\begin{tabular}{|c|c|c|}
\hline $\begin{array}{c}\text { Adaptability of } \\
\text { SDMs } \\
\text { to Context }\end{array}$ & $\begin{array}{c}\text { Contract } \\
\text { Management }\end{array}$ & $\begin{array}{l}\text { Construction } \\
\text { Management }\end{array}$ \\
\hline $\begin{array}{l}\text { Collaboration } \\
\text { between the } \\
\text { Design and } \\
\text { Supervision } \\
\text { departments }\end{array}$ & $\begin{array}{l}\text { Invitation to } \\
\text { tender }\end{array}$ & $\begin{array}{r}\text { SDM project } \\
\text { procedures }\end{array}$ \\
\hline $\begin{array}{l}\text { Design } \\
\text { modification }\end{array}$ & $\begin{array}{c}\text { Tendering } \\
\text { criteria }\end{array}$ & $\begin{array}{l}\text { Decision-making } \\
\text { process }\end{array}$ \\
\hline $\begin{array}{l}\text { Material } \\
\text { specifications } \\
\text { amendment }\end{array}$ & Payment process & $\begin{array}{l}\text { Communication } \\
\text { and cooperation }\end{array}$ \\
\hline Central database & $\begin{array}{l}\text { Contract } \\
\text { documents for } \\
\text { future SDM } \\
\text { projects }\end{array}$ & $\begin{array}{l}\text { Methodology for } \\
\text { identifying, } \\
\text { capturing, } \\
\text { documenting and } \\
\text { re-using LL }\end{array}$ \\
\hline $\begin{array}{l}\text { Dissemination } \\
\text { of LL }\end{array}$ & & $\begin{array}{l}\text { SDM project } \\
\text { closeout report }\end{array}$ \\
\hline
\end{tabular}

\subsection{Adaptability of the SDMs to Site Context- Related CSFs}

SDM projects are intended to be adapted to each unique specific site requirements, for instance, modifications in site layouts to accommodate topography, or property lines, structural, electrical and mechanical requirements. To achieve this aim, essential procedures are required in terms of survey data, soil investigation, site grading and the necessary design amendment for each model. The participants argued that CSFs are correlated at this stage based on the findings and by considering this stage as a core for each adopted SDM project, which involves some modifications in design or material specifications based on LL. The majority of interviewees discussed the repetitive faults detected in the prototype which caused some delays, which adversely affected the execution of SDM projects. The participants stressed that there are CSFs related to the adaptability of the SDMs to the specific site's context which call for well coordinated collaboration between the design and supervision departments in the client's head office. These overlooked factors affected the improvement of the SDM project performance, which resulted in a critical gap between those departments and contributed to the recurrence of the same faults in future SDM projects, which in turn acted as a significant impediment for improving project performance in SDM projects. The interviewees identified that design modification and material specification amendments emerged as significant CSFs because of their role in continuously improving the performance of SDM projects. Those factors were the result of existing communication and collaboration inefficiencies between the design and supervision departments during the adaptability stage, and propelled by the slow decision making process of the client during the construction stage. Additionally, the participants identified that there is a bleeding of LL because of the lack of a clear mechanism of learning defined by the client as well as a central database that provides shared and reusable LL. Indeed, the findings showed a shortage of the dissemination of LL, and as such the research participants called for a shared knowledge central database, which was recognised as an important CSF that affects the improvement for SDM projects because of its role in storing LL. Additionally, the interviewees argued that there is a focus on the role of disseminating LL to maintain continuous performance improvements within all on-going and future SDM projects; however, there were few examples of this dissemination in practice and what was being shared was being done manually. However, the participants argued that the adaptability stage exceeded the limited time (90 days) specified in the contract, and had extended up to about 150 days. This was due to a lack of a clear methodology developed between the three stakeholders (client, contractor and consultant).

\subsection{Contract Management-Related CSFs}

For contract management-related CSFs, all eight cases were based on an "open invitation" approach that provided an opportunity for all of the contractors to provide bids regardless of the focus on pre-qualification measures. However, in all eight cases, the lowest price was the tendering criterion used by the client to award a project to a contractor, which contributed to an ineffective identification and capture of LL by the majority of contractors because of a shortage of skilled staff with sufficient training and experience in construction projects and the lack of adequate resources. The participating stakeholders argued that the importance of financial power, relevant experience and the contractor's previous performance should be measures that must be involved in the selection of a contractor. They went further to suggest that there is a need to adopt a "closed invitation" and a long-term contract.

The improvement of the payment process emerged as a CSF because of its direct impact on the progress of the project, which ensured that the contractors' requests for payment were paid to the contractor on time. As argued by all participants, in all eight case studies, the payment processes were long and complicated, which contributed to the slow progress. The nature of SDM projects underlines the importance of reviewing contractor's documents based on LL in the completed projects. The findings revealed major mistakes that recurred in SDM project documents because captured LL was not reused from completed projects. For example there were major mistakes identified in the BoQ in terms of quantities or the description of some items which created grey areas for the contractors.

\subsection{Construction Management- Related CSFs}


Of the construction management-related CSFs, the SDM project procedures suffered from lack of an organised mechanism that focused on the standardisation of material procurement and logistical procedures to facilitate project progress in terms of approval of materials and inspection requests. Although a form of standardised procedures is being used, there is a lack of standardised procedures within all SDM projects, which has led to variation in project procedures for each geographic region. The current standardised procedures were established by the regional administration and contributed to a considerable improvement in project performance, particularly in terms of time/project schedule. The majority of participants identified that the decision-making process had also suffered from difficulties in making the right decision at the right time in all eight cases because of ambiguity and the limited authority granted to the project management team by the client. Therefore, the regional administration performed some trials to solve the detected problems inhouse. In all eight case studies, LL were fragmented, unorganised or missing because of the lack of a clear methodology that could guide their successful identification, capture, documentation and re-use. Many issues were highlighted in relation to LL inadequacies, such as a lower than expected commitment to learning by the client, a lack of a learning culture by all stakeholders, unskilled staff employed by the contractor and consultants, which negatively impacted on the value of LL. Furthermore, previous SDM project close-out reports were not used in any of the eight case studies and emerged as a CSF because of their pivotal role in providing a comprehensive assessment of every aspect of each project. The interviewees suggested that there is a need to create a number of classes or seminars that could guide the stakeholders as well as help determine the roles and responsibilities of each party and enable team collaboration.

\section{Framework Development}

The research participants concurred that there is a lack of learning instruments to capture, store and disseminate LL in the SDM projects. Thus, an organised and systematic framework was required that could be achieved by utilising the characteristics of SDM projects and the concept of learning. The literature review and the analysis of data collected from the eight case studies formed a basis for developing the improvement framework for SDM project performance. Weiser and Morrison (1998) noted that systematic methods of identifying, capturing and transferring LL for future projects are only present in a few firms. Accordingly, the need for a methodology for capturing and reusing the project knowledge during the execution of a project is critical, especially where this knowledge can be presented in a format to be reused for on-going and future projects.

\subsection{Purpose of the Framework}

The framework was proposed to capture the CSFs that are related to the improvement of the SDM project performance. The identified CSFs were classified into three framework components that influence the improvement of the SDM project performance. The proposed framework was thus developed to achieve the following;

1. Pinpoint the key CSFs that affect the improvement of SDM project performance, thereby providing an opportunity for stakeholders to identify areas requiring improvement to achieve sustained improvement.

2. Provide architectural guidance that allowed for interfacing design by using abstract classes that described functional factoring by specifying the roles and responsibilities and collaborations between the abstract classes.

3. Provide a systematic and organised method for capturing, sharing and reusing knowledge for all SDM projects.

4. Provide a set of guides that describe the CSFs required to improve the SDM project performance and how they are interrelated in an organised and integrated system.

5. Provide a basis to enable project managers to implement and assess the SDM project improvement process.

\subsection{Framework Structure and Contents}

The framework presents a holistic roadmap of the components that influence the SDM project performance improvement process. The framework, as shown in Figure 1 , is comprised of four phases in a chronological sequence, where each phase describes one component, i.e., the design modification phase (adaptability of SDMs to the context), the pre-construction phase (management of contracts), the construction phase (construction management) and the post-project audit (LL, database), which is linked with an LC that can be used as an indicator for the achieved improvement in SDM project performance. The four phases were identified and classified based on the current process used by the SMoI to implement SDM projects. The framework's phases are linked through feedback loops to transfer LL that are captured in each phase to provide shared knowledge, and thereby contributing to the improvement of the performance of on-going and future SDM projects.

\subsubsection{Design modification phase}

This phase encompasses input factors, which are in the form of CSFs related to the adaptability of the SDM to the context. In this phase, there are processes in which design modification and material specification amendments are performed. In addition, there is a need for collaboration between the design and supervision departments based on lessons gained by project management, which can be transferred from on-going and completed SDM projects. Accordingly, synergy and collaborative work between the design and construction teams could lead to a better outcome based on LL from previous experiences. Scott and Harris (1998) demonstrated that when design's faults are identified, recognised and presented in an accessible way to designers of future projects, improvements can be achieved. As shown in Fig. 1, forward and backward loops were provided by headed arrows that were linked to the next phase, i.e., the pre-construction phase, and to the same phase for other typical SDM projects. Similarly, forward and backward directions show information flow from phase to phase to organise the information processing. In all phases, recommended responsibilities were allocated to the relevant stakeholders involved in each phase. 


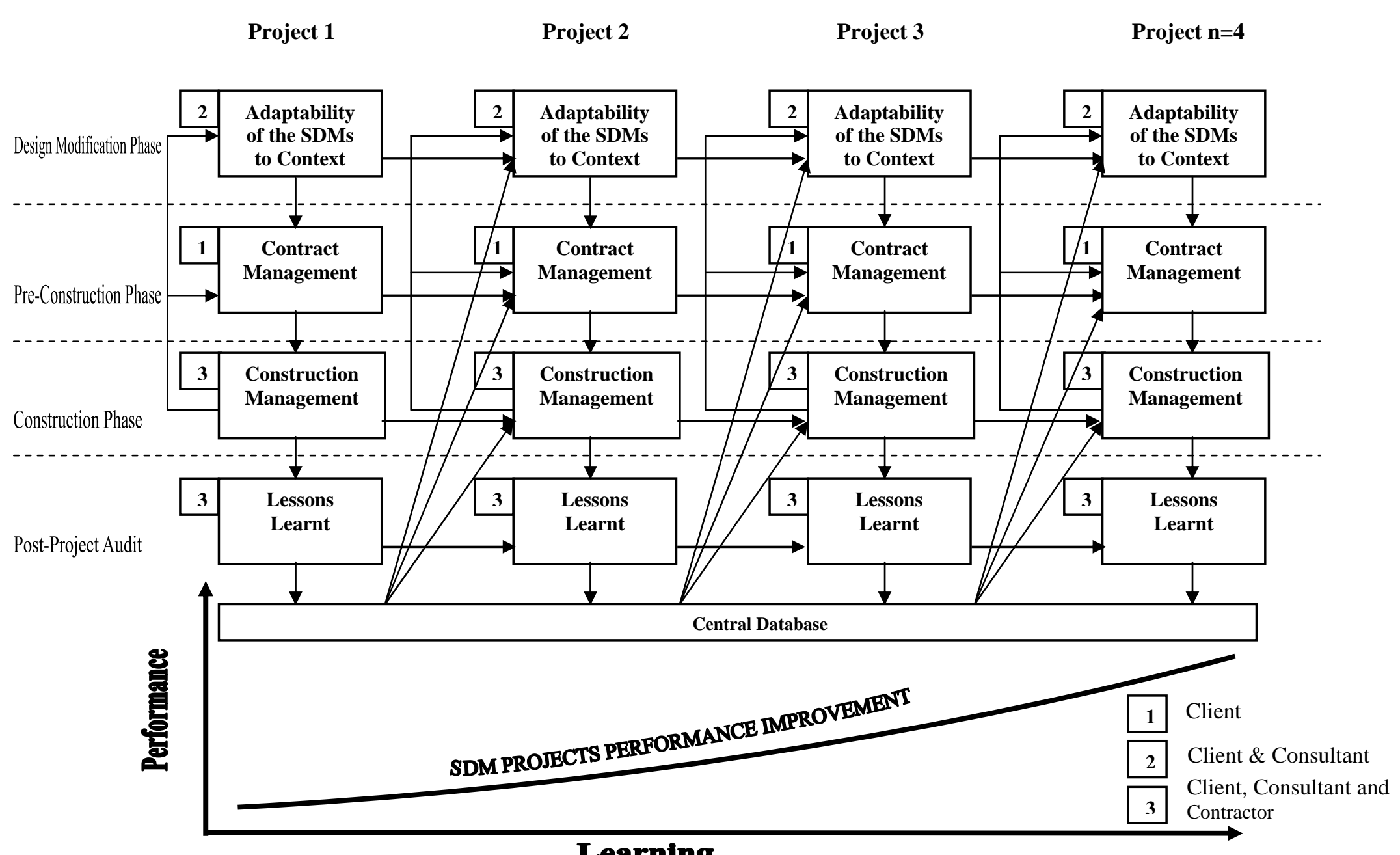

Construction Phase

Learning

Fig. 1. SDM projects performance improvement framework 


\subsubsection{Pre-construction phase}

This phase integrates input factors in the form of CSFs, which are related to the management of contracts. This phase includes processes involving the invitation to tender, the tendering process, the payment process, and the contract document. These processes can be based on the LL from on-going and completed SDM projects because the changes that are made during the construction phase affect the quantities involved in the BoQ, and therefore affect the cost of the project and the request for payment. Additionally, recommendations were forwarded for future SDM projects to take these changes into consideration during the preparation stage.

\subsubsection{Construction phase}

This phase comprises input factors in the form of CSFs identified as affecting the capture of LL related to the construction phase. These factors include SDM project's procedures, and promptness of the decision-making process, which encourages the capture of LL and innovation to disseminate the captured knowledge. This phase also includes communication and cooperation between all stakeholders in inter- or intra-SDM projects, which is one of the effective tools for promoting the exchange of knowledge; adopting a rigorous methodology for identifying, capturing, documenting and reusing LL from the SDM projects.

\subsubsection{Post-project audit phase}

This phase comprises the outputs from the construction phase, which are mainly LL and the SDM project's closeout report. LL and SDM project's closeout reports are reviewed and assessed so that they can be provided to the central database in the client's head office. Newell et al. (2006) criticised the limited use of databases that are built by transferring lessons from one project to another. Accordingly, a significant reduction in the time spent on problem solving and an increase in the quality of work can be achieved through the reuse of existing organisational knowledge, which is gained through experience (Dave and Koskela, 2009). The roles of key decision makers are shown as previously stated. The central database is linked with the three phases to be fed by the LLs that were obtained from completed SDM projects to improve future SDM projects. This process can be followed by measuring the improvement of the SDM project performance by using the learning curve, which employs the accumulative learning versus project performance criteria with respect to time, cost, quality, and client satisfaction.

\subsection{Framework Implementation Process Map}

The development of the SDM project performance framework shown in Fig. 1 was followed by formulating a process map for the Framework implementation as illustrated in Fig. 2 and Table 2. The map clarifies each component in terms of implementation responsibilities and how simultaneous projects are being implemented and learning from others through the improvement framework. The map works by using three phases of framework which are: adaptability of SDM to site context; contract management and construction management. It also shows the flow of information between projects through the three components and central database; the relationship between all relevant teams; responsibilities granted to those teams; and how learning could be achieved. This process is used in future projects of SDM. Four teams were identified in order to manage the process of information flow between the projects and central database. Those teams are named as follow: SDM Knowledge Management Team (SDMKMT); SDM Adaptation Team (SDM-AT); SDM Tendering Team (SDM-TT); and Project Manager (PM) and Construction Management Team (CMT).

\section{1) SDM Knowledge Management Team (SDM-KMT)}

This team works under the umbrella of the Information Technology Department (ITD). The role of SDM-KMT is to manage and organise the knowledge base (i.e. the development of a Project Knowledge File for a project (PKF), as well as to manage all required communications between all teams over the three components. This team handles and disseminates LL, which will add value to the knowledge through information processing. This process involves organisation, classification, codification and arrangement, storing and dissemination of LL, which will be formulated into different types of files such as PDF, Word File, Spread Sheet, etc. The ITD creates accounts for various users with various authorised levels of access.

\section{2) Standard Design Model Adaptation Team (SDMAT)}

This team is correlated with adaptability of SDM to site, where the nature of adaptation requires a group of engineers working together to adapt the SDM to site context. Therefore, the SDMAT comprise a number of client and consultant engineers such as architectural engineer, civil engineer, electrical engineer, etc. The nature of current work in the adaptability of SDMs to context is that there is a programme that must be adapted simultaneously and continuously, and therefore, there is a determined team responsible for performing this task as described in Table 2.

\section{3) Standard Design Model Pre-construction Team (SDMPT)}

There is a need for the team to work together, and should be comprised of members of the client organisation such as quantity engineer, contract engineer, financial specialist, etc. The style of work in this component is similar to what is done in the adaptability of SDMs to site context. This is because the same package of projects which were adapted are provided to the SDM-PT to be prepared for the tendering process and awarding projects to contractors.

4) Project Manager (PM) and Construction Management Team (CMT)

In the execution of project there is a team involving the contractor, consultant and client. This team is engaged with the project manager who is assigned by the client's head office and is linked with regional administration. In this component, every project is managed separately in terms of contractor, consultant and client as well as different local location and geographic regions. 


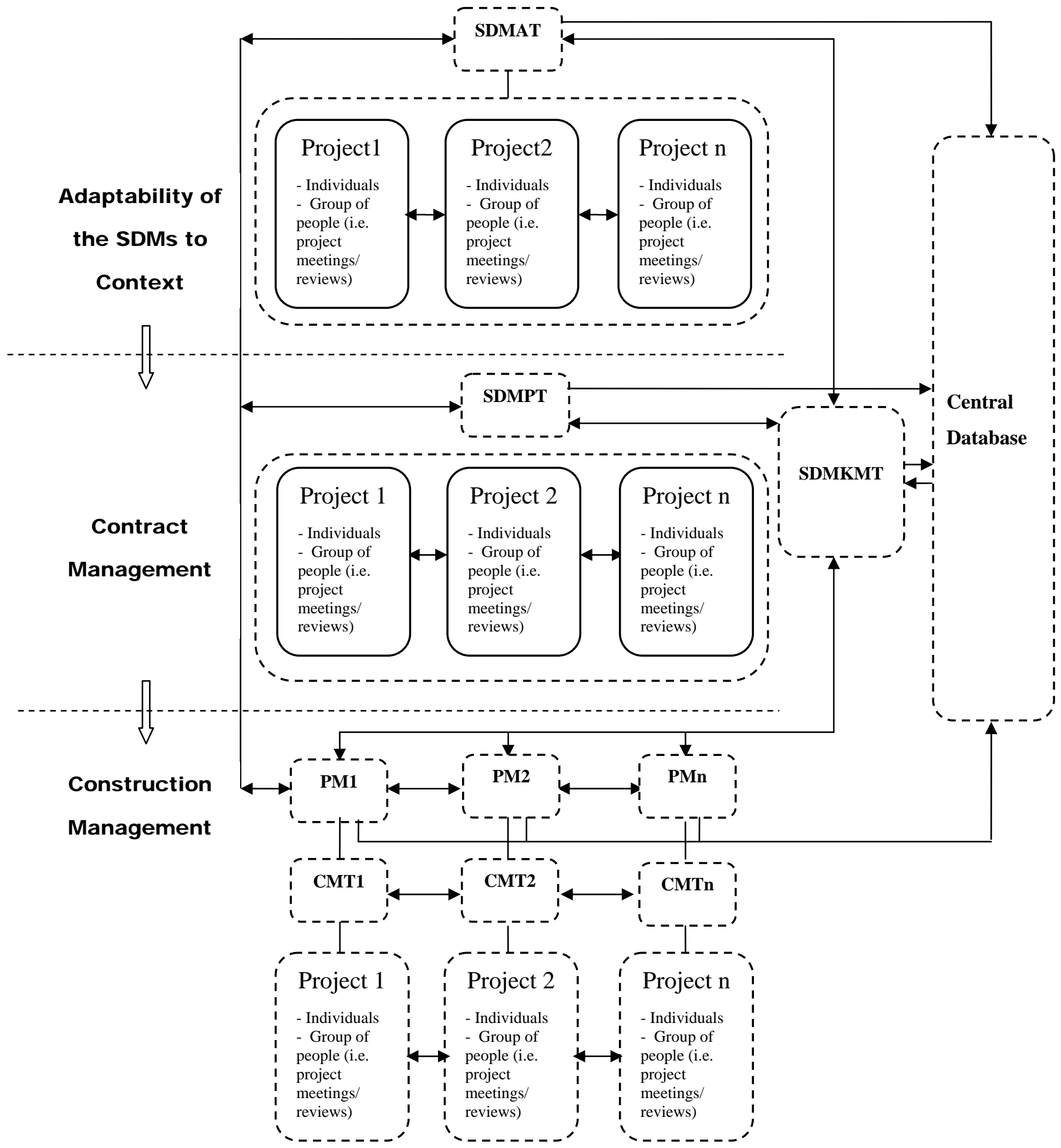

Legends

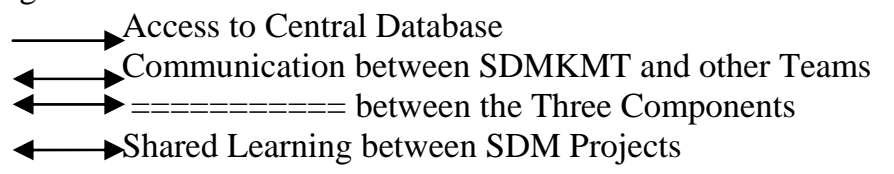

Fig. 2. Framework process map 
Table 2. Components involved in the framework process map

\begin{tabular}{|c|c|c|c|c|}
\hline Component & Team & Process & Responsibility & Communication \\
\hline $\begin{array}{l}\text { Adaptability of SDMs } \\
\text { to Context }\end{array}$ & $\begin{array}{l}\text { Standard Design Model Adaptation } \\
\text { Team (SDM-AT): the nature of } \\
\text { adaptation requires a number of } \\
\text { engineers working together to adapt } \\
\text { the SDM to context. Therefore, the } \\
\text { SDM-AT comprises a number of } \\
\text { clients and consultant engineers } \\
\text { such as architectural and civil } \\
\text { engineers }\end{array}$ & $\begin{array}{l}\text { During the adaptation works, } \\
\text { SDMAT is charged to identifying, } \\
\text { capturing LL from project } \\
\text { meetings/reviews, individuals and } \\
\text { from making changes to project } \\
\text { documents (such as engineering } \\
\text { drawings). The validation process is } \\
\text { important task for the LL identified } \\
\text { and captured in the system. The LL } \\
\text { identified and captured from a } \\
\text { group (i.e. meetings and reviews) is } \\
\text { deemed to have been validated in } \\
\text { the meetings or reviews, whereas } \\
\text { the LL submitted by individuals } \\
\text { may need to be validated prior to } \\
\text { reuse. The identified and captured } \\
\text { LL can simultaneously be shared } \\
\text { within the package of projects. } \\
\text { Finally, to protect LL from missing } \\
\text { due to the time lapse, they are sent } \\
\text { "live" to SDMKMT via electronic } \\
\text { file designed by SDMKMT to be } \\
\text { processed in order to be stored into } \\
\text { a central database to be reused for } \\
\text { on-going and future SDM projects. }\end{array}$ & $\begin{array}{l}\text { SDMAT is responsible for } \\
\text { performing adaptation requirements } \\
\text { in terms of required changes based on } \\
\text { the requirements of each site which } \\
\text { are affected by geographical factors, } \\
\text { soil investigation results, surveying } \\
\text { results, etc. This is followed by } \\
\text { reviewing electrical, mechanical and } \\
\text { civil works, etc. }\end{array}$ & $\begin{array}{l}\text { SDMAT has communications with } \\
\text { SDMKM as mentioned above, } \\
\text { Standard Design Model Pre- } \\
\text { construction Team (SDMPT) and } \\
\text { Project Managers (PMs). The } \\
\text { communication with SDMPT comes } \\
\text { according to two levels: first is a } \\
\text { communication in relation to } \\
\text { providing the adapted SDM projects } \\
\text { to be processed into the pr- } \\
\text { construction phase, and second is a } \\
\text { communication for discussing arisen } \\
\text { issues which often create new lessons. } \\
\text { The communication with PMs is to } \\
\text { address the problems/suggestions } \\
\text { related to adaptation phase which } \\
\text { arising during SDM projects } \\
\text { implementation and almost producing } \\
\text { new lessons. SDMAT has an access } \\
\text { into a database to only get the needed } \\
\text { information via a web-based system }\end{array}$ \\
\hline Contract Management & $\begin{array}{l}\text { SDMPT: in this component, there is } \\
\text { a need to team working together } \\
\text { comprising a number of members } \\
\text { of client such as quantity engineer, } \\
\text { contract engineer, financial } \\
\text { specialist, etc. }\end{array}$ & $\begin{array}{l}\text { In this component, SDMAT follows } \\
\text { the same process identified in the } \\
\text { adaptability phase except the } \\
\text { difference in type of works which } \\
\text { focuses on preparation of project to } \\
\text { be tendered and awarded to } \\
\text { contractor. }\end{array}$ & $\begin{array}{l}\text { SDMPT is responsible for producing } \\
\text { project contract documents, project } \\
\text { cost estimation, performing tendering } \\
\text { and awarding process. }\end{array}$ & $\begin{array}{l}\text { SDMPT has communications with } \\
\text { SDMKM as mentioned above, } \\
\text { SDMAT and PMs. The } \\
\text { communication with SDMAT was } \\
\text { described above. The communication } \\
\text { with PMs is to address the } \\
\text { problems/suggestions related to } \\
\text { contract management which arising } \\
\text { during SDM projects implementation } \\
\text { and almost producing new lessons. } \\
\text { SDMPT has an access into a database } \\
\text { to only get the needed information via } \\
\text { a web-based system. }\end{array}$ \\
\hline
\end{tabular}




\begin{tabular}{|c|c|c|c|c|}
\hline Component & Team & Process & Responsibility & Communication \\
\hline $\begin{array}{l}\text { Construction } \\
\text { Management }\end{array}$ & $\begin{array}{l}\text { Project Manager (PM) and } \\
\text { Construction Management Team } \\
\text { (CMT): in the execution of project } \\
\text { there is a team involving contractor, } \\
\text { consultant and client. This team is } \\
\text { engaged with project manager who } \\
\text { is assigned by client's head office } \\
\text { and is linked with regional } \\
\text { administration. }\end{array}$ & $\begin{array}{l}\text { CMT follows the same process } \\
\text { identified through the } \\
\text { aforementioned components in } \\
\text { terms of identification and capture } \\
\text { and validation the LL. However, in } \\
\text { such case, every project is being } \\
\text { implemented separately under one } \\
\text { PM and CMT which is different } \\
\text { than the previous components, } \\
\text { where package of project are } \\
\text { adapted and prepared under one } \\
\text { team. Consequently, project-to } \\
\text { project learning can be achieved } \\
\text { through two ways. First, the SDM } \\
\text { projects which are being } \\
\text { implemented can learn from others } \\
\text { through having an access into } \\
\text { central database via a web-based } \\
\text { system. Second, they can learn } \\
\text { through communication with other } \\
\text { SDM projects located in the same } \\
\text { area via regular visits and meetings. } \\
\text { At the end of project, CMTs are } \\
\text { charged to provide close-out report } \\
\text { to PMs in order to be sent to } \\
\text { SDMKMT. }\end{array}$ & $\begin{array}{l}\text { CMT is responsible for following the } \\
\text { implementation of project according } \\
\text { to determined schedule and holding } \\
\text { regular meetings/reviews to assess } \\
\text { the project performance. This comes } \\
\text { with a full cooperation with project } \\
\text { manager who can be a member in } \\
\text { every meeting/review. } \\
\text { Responsibilities are similar in every } \\
\text { SDM project implemented in } \\
\text { different location. }\end{array}$ & $\begin{array}{l}\text { PM has communications with } \\
\text { SDMAT, SDMPT and SDMKMT as } \\
\text { explained above. However, in this } \\
\text { component and in particular if there } \\
\text { are a number of SDM projects } \\
\text { implemented simultaneously in the } \\
\text { same area, there are communications } \\
\text { between Projects Managers as well as } \\
\text { CMTs to discuss the hot issues and } \\
\text { then exchange needed information, } \\
\text { skills, experiences, and therefore, } \\
\text { these information could be formed as } \\
\text { LL and provided to SDMKMT } \\
\text { through PMs. Additionally, learning } \\
\text { could be created through regular } \\
\text { meetings between all teams in the } \\
\text { three components to discuss the } \\
\text { important issues. }\end{array}$ \\
\hline
\end{tabular}


Table 3. Validation results of the improvement framework

\begin{tabular}{|c|c|c|c|c|c|c|c|c|c|c|}
\hline \multirow{2}{*}{ Questions } & \multicolumn{9}{|c|}{ Participants' score } & \multirow{2}{*}{$\frac{\text { Average }}{\text { Score }}$} \\
\hline & A1 & A2 & A3 & B1 & B2 & B3 & C1 & C2 & C3 & \\
\hline $\begin{array}{l}\text { 1. Provision of stages needed } \\
\text { to improve SDM' project } \\
\text { performance }\end{array}$ & 4 & 5 & 4 & 5 & 5 & 5 & 5 & 5 & 4 & 4.7 \\
\hline $\begin{array}{l}\text { 2. Comprehensive coverage } \\
\text { of SDM' project performance } \\
\text { CSFs }\end{array}$ & 5 & 5 & 4 & 5 & 4 & 4 & 4 & 5 & 3 & 4.3 \\
\hline $\begin{array}{l}\text { 3. Providing/sharing } \\
\text { knowledge }\end{array}$ & 4 & 5 & 5 & 5 & 5 & 4 & 4 & 4 & 4 & 4.4 \\
\hline $\begin{array}{l}\text { 4. Lessons learnt needed } \\
\text { as a tool for improvement } \\
\text { process }\end{array}$ & 5 & 5 & 4 & 4 & 5 & 5 & 5 & 5 & 5 & 4.8 \\
\hline $\begin{array}{l}\text { 5. Support for knowledge } \\
\text { management }\end{array}$ & 5 & 5 & 5 & 4 & 5 & 5 & 4 & 4 & 3 & 4.4 \\
\hline $\begin{array}{l}\text { 6. SDM' project performance } \\
\text { improvement is assessed } \\
\text { and measured }\end{array}$ & 5 & 5 & 5 & 4 & 4 & 5 & 4 & 5 & 5 & 4.7 \\
\hline $\begin{array}{l}\text { 7. Structured methodology } \\
\text { for improving SDM' } \\
\text { project performance }\end{array}$ & 4 & 5 & 4 & 5 & 5 & 5 & 4 & 4 & 5 & 4.6 \\
\hline $\begin{array}{l}\text { 8. Supports performance } \\
\text { improvement for future } \\
\text { projects }\end{array}$ & 5 & 5 & 5 & 5 & 5 & 4 & 5 & 5 & 4 & 4.8 \\
\hline $\begin{array}{l}\text { 9. Providing potential } \\
\text { learning }\end{array}$ & 5 & 5 & 5 & 4 & 5 & 5 & 5 & 5 & 4 & 4.8 \\
\hline \multicolumn{11}{|l|}{$\begin{array}{c}\text { Framework implementation } \\
\text { strategy }\end{array}$} \\
\hline 1. Web based tool & 5 & 5 & 5 & 5 & 5 & 5 & 5 & 4 & 5 & 4.9 \\
\hline 2. Manual project file & 4 & 4 & 5 & 2 & 2 & 1 & 1 & 1 & 2 & 2.4 \\
\hline $\begin{array}{l}\text { 3. Knowledge Management } \\
\text { (KM) }\end{array}$ & 5 & 4 & 5 & 5 & 5 & 4 & 5 & 5 & 5 & 4.8 \\
\hline 4. Existing KM & 5 & 4 & 5 & 5 & 5 & 4 & 5 & 5 & 5 & 4.8 \\
\hline General aspects of framework & \multicolumn{10}{|c|}{$1=$ very weak \& 5 = very strong } \\
\hline $\begin{array}{l}\text { 1. Practicality of the } \\
\text { framework }\end{array}$ & 3 & 4 & 4 & 5 & 4 & 5 & 4 & 4 & 3 & 4 \\
\hline $\begin{array}{l}\text { 2. appropriateness of the } \\
\text { framework }\end{array}$ & 4 & 5 & 4 & 5 & 5 & 5 & 5 & 5 & 4 & 4.7 \\
\hline $\begin{array}{l}\text { 3. Clarity of the } \\
\text { framework }\end{array}$ & 4 & 5 & 4 & 5 & 5 & 5 & 5 & 5 & 5 & 4.8 \\
\hline
\end{tabular}

\subsection{Framework Validation}

The workshop participants were stakeholders who were involved in the implementation of SDM projects. The aim of the validation exercise was to test the implementation of the Framework in terms of practicality, clarity and appropriateness. The following objectives of the framework validation were proposed.

1. To discuss and seek agreement about the findings and major issues that are presented in the Framework and their effects on the improvement of SDM project performance.

2. To discuss and validate the framework's critical success factors (CSFs) and their influence on SDM project performance improvement.
3. To discuss and validate the CSFs by reference to best practices.

\subsubsection{Assessment of the improvement framework}

Table 2 shows the Framework validation Likert Scale results in terms of practicality, appropriateness, and clarity. Two types of scale ranges were used; the first was from 1 (strongly disagree) to 5 (strongly agree), whereas the second was from 1 (very weak) to 5 (very strong). The results revealed that the clarity of the Framework was highly rated by the participants, where it achieved an overall score of 4.8; the appropriateness also achieved an overall score of 4.7. The practicality of the Framework was given a slightly lower score of 4.00 because of the length of time required for the practical implementation. Additionally, the Framework was assessed in terms of its 
components, such as the comprehensiveness of coverage of CSFs that were based on LL, and the provision of the stages needed. There were some differences among the mean ratings of the latter aspects, but they were mainly very small, with a highest mean rating of 4.8 and a lowest of 4.3 , as shown in Table 3 . Indeed, it can be seen that 'supporting performance improvement for future SDM projects', 'LL needed as a tool for improvement process', and 'providing potential learning' received the highest levels of agreement, with a mean of 4.78 .

\subsubsection{Validation of the implementation strategy of the framework}

Web-based tools and knowledge management (KM), as illustrated in Table 4, received high ratings of agreement and as a whole the assessment of all the items were acknowledged by the validation workshop participants as critical factors in the Framework implementation strategy. Web-based tools had the strongest levels of agreement with an average of 4.9, which was followed by KM with an average value of 4.8. The participating stakeholders commented that there is currently no KM used in the SDM projects. A project manual file does exist; however, it is not executed in its full form. Web-based tools, knowledge management (KM), and existing $\mathrm{KM}$ received the highest rating of agreement with means of 4.9, 4.8 and 4.8, respectively; however, the project manual file received the lowest rating of agreement, with a mean of 2.4.

\section{Conclusions}

This research work explored how SDM project performance can be improved. Therefore, the focus was to identify the critical factors that have direct impact on developing a workable and valid framework for the SDM projects. Therefore, the developed framework was built based on identifying the CSFs that have a major impact on improving the SDM projects. An integrated improvement process was established simulating the reality of SDM projects by involving the determined CSFs through three key stages: the design adaptation of SDMs to site context, contract management and construction management, to facilitate the application of learning in SDM projects. An improved framework was proposed for improving the performance of SDM projects based on learning, which was tested through a validation workshop conducted in the context of SDMs in Saudi Arabia. The use of the learning curve (LC) as a tool for measuring the improvement achieved was based on cumulative learning and performance throughout the implementation of the SDM approach. Web-based tools and KM were identified as core factors in the Framework implementation strategy. A Framework implementation process map was developed, that clarifies each component in terms of the implementation organisational and individual responsibilities as well as management and dissemination of LL.

Further research area is required to develop a framework for improving the facilities management performance based on the end-users' views, which would serve as a feedback channel to be used in the design adaptation of the SDM stage to achieve better efficiency and quality for future SDM buildings. Also, the impact of using the Building Information Modeling (BIM) in the performance of SDM projects is another further research.

Table 4. Validation of the framework implementation strategy

Framework Implementation Strategy

1 = strongly disagree \& 5 = strongly agree

\begin{tabular}{|c|c|c|c|c|c|c|c|c|c|c|}
\hline \multirow{2}{*}{ Questions } & \multicolumn{9}{|c|}{ Participants' score } & \multirow{2}{*}{$\begin{array}{c}\text { Average } \\
\text { Score }\end{array}$} \\
\hline & A1 & A2 & A3 & B1 & B2 & B3 & C1 & $\mathrm{C} 2$ & C3 & \\
\hline \multicolumn{11}{|l|}{$\begin{array}{c}\text { Framework implementation } \\
\text { strategy }\end{array}$} \\
\hline 1. Web based tool & 5 & 5 & 5 & 5 & 5 & 5 & 5 & 4 & 5 & 4.9 \\
\hline 2. Manual project file & 4 & 4 & 5 & 2 & 2 & 1 & 1 & 1 & 2 & 2.4 \\
\hline $\begin{array}{l}\text { 3. Knowledge Management } \\
\text { (KM) }\end{array}$ & 5 & 4 & 5 & 5 & 5 & 4 & 5 & 5 & 5 & 4.8 \\
\hline 4. Existing KM & 5 & 4 & 5 & 5 & 5 & 4 & 5 & 5 & 5 & 4.8 \\
\hline
\end{tabular}

\section{References}

Al-Kharashi, A. and Skitmore, M. (2009). Causes of delays in Saudi Arabian public sector construction projects. Construction Management and Economics, 27(1), 3-23.

Al-Otaibi, S., Osmani, M., and Price, A.D.F. (2008). Standard Design Model as an enabler for project management competency. ICOPM, Proceedings: International Conference on Project Management (ICoPM), Achieving Excellence through Project Management, Petaling Jaya, Malaysia.

Al-Otaibi, S., Osmani, M., and Price, A.D.F. (2007). Approach of standard design models in the Saudi Ministry of Interior projects. C. Egbu and M. Tong, Proceedings of The Third Scottish Conference for
Post Graduate Researchers of the Built and Natural Environment - PRoBE, Glasgow, 55-65.

Arain, F. M., Pheng, L.S., and Assaf, S.A. (2006). Contractors' Views of the Potential Causes of Inconsistencies between Design and Construction in Saudi Arabia. Journal of Performance of Constructed Facilities, 20(1), 74-83.

Ashley, D.B., Laurie, C.S., and Jaselskis, E.J. (1987). Determinants of construction project success. Project Management Journal, 18(2), 69-79.

Atkinson, B., Borgbrant, J., and Josephson, P. (2003). Construction Process Improvement. Oxford: Blackwell Publishing.

Barrie, G. (1999). Clients group calls for contractors league tables. Building, 264(17), 10.

Belassi, W. and Tukel, O.I. (1996). A new framework for determining critical success/failure factors in projects. 
International Journal of Project Management, 14(3), 141-151.

Belout, A. and Gauvreau, C. (2004). Factors influencing project success: the impact of human resource management. International Journal of Project Management, 22(1), 1-11.

Bryman, A. (2008). Social Research Methods, 2nd edition. Oxford University Press, Oxford.

Chan, A. P. C., Ho, D. C. K., and Tam, C. M. (2001). Design and build project success factors: multivariate analysis. Journal of Construction Engineering and Management, 127(2), 93-100.

Chan, D. W. and Kumaraswamy, M. M. (1995). A study of the factors affecting construction durations in Hong Kong. Construction Management and Economics, 13, 319-333.

Chinowsky, P., Molenaar, K., and Realph, A. (2007). Learning Organizations in Construction. Journal of Management in Engineering, 23(1), 27-34.

Chua, D.K.H., Kog, Y.C., and Loh, P.K. (1999). Critical success factors for different project objectives. Journal of Construction Engineering and Management, 125(3), 142-150.

Cook, A. (1999). Wanted: Egan converts with industrial leanings. Building, 264 (34), 20-21.

Cooke-Davies, T. (2002). The "real" success factors on projects. International Journal of Project Management, 20(3), 185-190.

Crossan, M.M., Lane, H.W., and White, R.E. (1999). An organizational learning framework: from intuition to institution. Academy of Management Review, 24(3), 522-37.

Crossan, M.M., Lane, H.W., and White, R.E. (1997). Organisational learning: toward a theory. Working paper Series, Richard Ivey School of Business, 98-05 and 1-54. London.

Dainty, A.R.J., Cheng, M., and Moore, D.R. (2003). Redefining performance measures for construction project managers: an empirical evaluation. Construction Management and Economics, 21(2), 209-218.

Dave, B. and Koskela, L. (2009). Collaborative knowledge management-A construction case study. Automation in Construction, 18(7), 894-902.

DETR (1999a). Contractors lead race to improve performance. Construction Monitor, Department of the Environment, Transport and the Region, 8.

Egan Sir, J. (1998). Rethinking construction, Department of the Environment, Transport and Regions, London, UK.

Egbu, C. O. (1999). Skills, knowledge and competencies for managing construction refurbishment works. Construction Management and Economics Journal, 17(1), 29-43.

Fellows, R. and Liu, A. (2008). Research Methods for Construction, Blackwell Science, Oxford, London.

Fortune, J. and White, D. (2006). Framing of project critical success factors by a systems model. International Journal of Project Management, 24, 5365.

Gieskes, J. F. B. and ten Broeke, A. M. (2000). Infrastructure under construction: continuous improvement and learning in projects. Integrated Manufacturing Systems, 11(3), 188-198.

Goh, S. and Richards, G. (1997). Benchmarking the learning capability of organizations. European Management Journal, 15(5), 575-583.
Hussey, J. and Hussey, R. (1997). Business Research: A Practical Guide to Undergraduate and Postgraduate Students, Macmillan Press, London.

Johnston, W. J., Leach, M. P., and Liu, A. H. (1999). Theory testing using case studies in business-tobusiness research. Industrial Marketing Management, 28, 201-213.

Kalsaas, B. T. (2012). The last planner system style of planning: its basis in learning theory. Journal of Engineering, Project, and Production Management, 2(2), 88-100.

Kululanga, G. K., McCaffer. R., Price, A. D. F., and Fotwe-Edum, F. (1999). Learning mechanisms employed by construction contractors. Journal of Construction Engineering and Management, 125(4), 215-223.

Latham Sir, M. (1994). Constructing the Team, HMSO, London.

Law, K. M. Y. and Chuah, K. B. (2004). Project-based action learning as learning approach in learning organisation: the theory and framework. Team Performance Management, 10(7/8), 178-186.

Liu, A. M. M. (1999). A research model of project complexity and goal commitment effects on project outcome. Engineering, Construction and Architectural Management, 6(2), 105-11.

Low, S. P. and Chuan, Q. (2006). Environmental factors and work performance of project managers in the construction industry. International Journal of Project Management, 24(1), 24-37.

Miser, J. H. (1993). A foundational concept of science appropriate for validation in operational research. European Journal of Operational Research, 66(2), 204-215.

Newell, S., Bresnen, M., Edelman, L., Scarbrough, H., and Swan, J. (2006). Sharing knowledge across projects. Management Learning, 37(2), 167-185.

Ng, L.Y. and Mo, J. K. W. (1997). Hospital procurement by design and build: a case study in Hong Kong. Proceedings of CIB W92 Symposium, Procurement A Key to Innovation, Procurement Systems, 545-53.

Phua, F. T. T. and Rowlinson, S. (2004). How important is cooperation to construction project success? A grounded empirical quantification. Engineering Construction and Architectural Management, 11, 4554.

Pidd, M. (2009). Tools for Thinking: Modelling in Management Science, John Wiley and Sons, West Sussex, UK.

Pinto, I. K. and Slevin, D. P. (1989). Critical success factors in R\&D projects. Res. Technol. Management, 31-35.

Pinto, J. K. and Slevin, D. P. (1988) Critical success factors across the project life cycle. Project Management Journal, 19(3), 67-75.

Ritchie, J. and Spencer, L. (1994). Qualitative data analysis for applied policy research. In Bryman, A. and Burgess, R. G. Analysing Qualitative Data, 173194. London: Routledge.

Rockart, J. F. (1982). The changing role of the information system executive: a critical success factor perspective. MIT Sloan Management Review, 23(3), 3-13.

SAD (2008). Performance of Projects of Standard Design Models. Supervision Administrative, Annual Performance Review, 3, 2-189. 
SAD (2006). Performance of Projects of Standard Design Models. Supervision Administrative, Annual Performance Review, 1, 2-70.

Savindo, V., Grobler, F., Parfitt, K., Guvenis, M., and Coyle, M. (1992). Critical success factors for construction projects. Journal of Construction Engineering and Management, 118(1), 94-111.

Scott, S. and Harris, R. (1998). A methodology for generating feedback in the construction industry. The Learning Organization, 5(3), 121-127.

Smyth, H. (2010). Construction industry performance improvement programmes: the UK case of demonstration projects in the 'Continuous Improvement' programme. Construction Management and Economics, 28(3) 255-270.

Smith, J. H. (1993). Modeling muddles: Validation beyond numbers. European Journal of Operational Research, 66(2), 235-249.

Snider, K. F., Barrett, F. J., and Tenkasi, R. (2000). Considerations in acquisition lessons-learned system design. Acquisition Review Quarterly, Winter, 67-84

Songer, A. D. and Molenaar, K. R. (1997). Project characteristics for successful public-sector designbuild. Journal of Construction Engineering and Management, 123(1), 34-40.

Takim, R. (2005). A framework for successful construction project performance. $P h D$. thesis, Glasgow Caledonian University, Glasgow, UK.

Tan, H. C., Patricia M. Carrillo, P. M., Anumba, C. J., Bouchlaghem, N. D., Kamara, J. M., and Udeaja, C. E. (2007). Development of a Methodology for Live Capture and Reuse of Project Knowledge in Construction. Journal of Management in Engineering, 23(1), 18-26.

Tang, Y. H. and Ogunlana, S. O (2003). Selecting superior performance improvement policies. Construction Management and Economics, 21(3), 208-213.

Toor, S. R. and Ogunlana, S. (2009). Ineffective leadership Investigating the negative attributes of leaders and organizational neutralizers. Engineering, Construction and Architectural Management, 16(3), 254-272.

Wegelius-Lehtonen, T. (2001). Performance measurement in construction logistics. International Journal of Production Economics, 69(1), 107-116.

Weiser, M. and Morrison, J. (1998). Project memory: information management for project teams. Journal of Management Information Systems, 14(4), 149-66.

Yin, R. K. (2008). Case study research: Design and methods, Sage Publications, Thousand Oaks, CA.

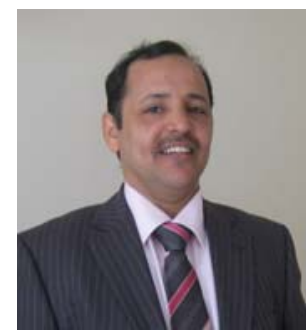

Shabbab is an Executive Manager in the Centre of Development Projects (CDP) at the Ministry of Interior as well as a Lecturer (part time) in the Civil Department, King Saud University. He obtained his BSc. in Civil Engineering 1993, followed by an MSc. in Civil Engineering 2000. Shabbab was awarded his PhD from Loughborough University in 2010 in Construction Management. His academic experience is complemented by 15 years of industrial experience in project management and strategic planning with the CDP. He has research interest in project performance improvement, construction design management and learning.

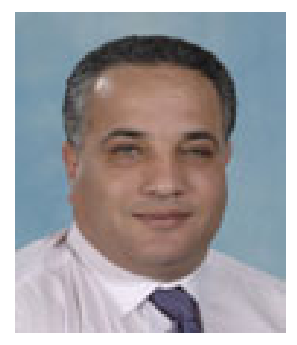

Mohamed Osmani is a Senior Lecturer in Architecture and Sustainable Construction and Director of the Architectural Engineering \& Design Management Programme. He is the Chairman of Construction Industry Research and Information Association (CIRIA) Sustainability Advisory Panel, which provides a focus on salient cross-cutting sustainable construction issues in the UK; Chair of a new suite of British Standard (BS 8895: Part 1 to Part 5); a member of the UK Strategic Forum in Construction; and Construction and Demolition Waste Task Leader of the International Waste Working Group (IWWG).

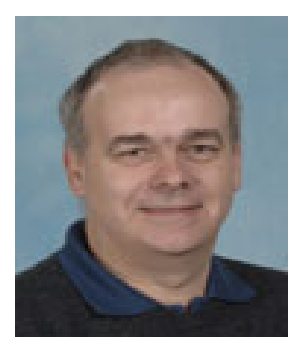

Andrew Price is a Professor in the School of Civil and Building Engineering. He is a Professor of Project Management / Director of Postgraduate Studies / Co-Academic Director of the Health and Care Infrastructure /Research and Innovation Centre (HaCIRIC). Professor Andrew has research interest in the innovative design and construction solutions for health and care infrastructure; continuous improvement; and sustainable urban. 